\section{Occurrence of Craspedacusta sowerbii, Lankester, in Monmouthshire}

Ar the end of August one of my students, Mr. H. Jenkins, sent me some medusæ which he had found in a reservoir at the Bedwellty Pits Colliery, Tredegar, Monmouthshire. They proved on examination to belong to Craspedacusta sowerbii, Lankester. The medusæ were very numerous and ranged from quite small specimens to those measuring at least half an inch in diameter. The reservoir was originally constructed to feed the boilers of the colliery, and is divided into three compartments. The medusæ were found in the central compartment only. This is 80 yards long, from 4 to 14 yards wide, and from 2 to 8 feet deep.

The water entering the reservoir is drainage water from the surrounding mountain-sides, which enters by two main inlet streams. There are no outlets except the pipes to the boilers and an overflow in very wet weather. The reservoir has been stocked from time to time by the local angling society with fish (perch, tench, roach and rudd) and with freshwater snails and mussels. No traces of the medusa were found in the inlet streams or in the Bedwellty Park ponds and the River Howy in the neighbourhood. This occurrence seems to me to be sufficiently remarkable and interesting to place on record.

University College, W. M. Tattersall. Cardiff.

\section{Spawning of Trout}

The remarks in Nature of August 26, p. 325, on the spawning of non-migratory trout raise some interesting points. In the Wiltshire and Hampshire chalk streams, an occasional trout is caught in September, which by its appearance is almost ready for spawning, but on these rivers spawning extends right up to the New Year.

The statutory close season on the Avon begins on October 16, and there is much controversy amongst fishermen of experience with regard to the right date to stop fishing. It is quite usual for fishing to cease on September 30, and the reason given is almost always that the fish before spawning feed more readily and are too easily caught. A minority assert that the fish rise well in the first week in October, are in excellent condition, and that some of the older fish, which are better out of the water, are taken. It will be seen that the trend of opinion here is contrary to the suggestion that there is a prespawning period of abstinence from food, or alternatively the date of general spawning on these rivers is rather later than that suggested in the note in NATURE.

It is a matter of common experience that trout, which are shy risers, are often taken late in September on fancy flies, when they are not taking the natural fly, which argues an abnormal appetite at this period.

Woodlands, Farnborough, A. H. HALL. Hants. Sept. 5.

Mr. HaLL's letter indicates that the problems in the life-history of the brown trout referred to in the note in Nature of August 26, p. 325, have an interest for anglers and owners of fisheries. It also shows that anglers themselves may assist with data that merit consideration. As Miall said many years ago, "much information . . . can be extracted from anglers by those who speak their language" (L. C. Miall, "The Natural History of Aquatic Insects").

It is likely that there are differences in the length and time of the spawning season in different types of river environments, and that meteorological factors may also exert a significant influence. That evidence on these points should be made available by those in a position to observe the facts is very desirable.

The question whether the trout's normal feeding is discontinued or diminished as spawning time approaches is one that can only be finally answered by the methods of exact research.

The Writer of the Note.

\section{Strawberry Root Rot in England}

DURING the past five or six years I have been specially interested in strawberry 'black root' or 'root rot' in relation to its effect on the deterioration of strawberry plantations in America, especially in Ontario, Canada. In many localities in the United States of America and in Canada 'root rot' is a factor of great importance and is considered by many as being one of the fundamental causes of 'failure' in strawberry cultivation. So important is this trouble considered to be that it is now being critically studied in many laboratories in the United States of America and in Canada, among others at St. Catharines, Ontario, Canada, by Walker and Hildebrand under my direction.

Various fungi have been isolated from the root lesions, and at St. Catharines, Ontario, Walker ${ }^{1}$ has obtained evidence that one of these, a Ramularia sp. is pathogenic. Strong and Strong ${ }^{2}$, working in Michigan, have also shown that root rot (black root) may be caused by Coniothyrium sp. and by Hainesia lythri. Also Zeller ${ }^{3}$ in Oregon has demonstrated that Rhizoctonia Solani is the cause of a similar root rot condition in Oregon. What appears to be a similar disease has also been reported from Washington, Utah, New York, in the United States of America; and from Australia, Scotland and France.

The symptoms of 'root rot' are a general lack of vigour throughout the plant resulting in pronounced dwarfing of leaves and petioles, and a much reduced root system. The leaves take on a brownish tint and in time wilt and die. On the root, definite and conspicuous black lesions are apparent. In severe attacks the bulk of the lateral roots rot away, and the main roots show a profusion of black lesions.

Shortly after my arrival in England (on a year's visit under the 'exchange' system) I had occasion to visit a number of strawberry plantations in various parts in the south and west of England, and my interest was immediately roused by the fact that in many plantations numerous plants showed symptoms of disease similar to those associated with 'root rot' in Canada. On examining the roots of such plants I found that definite lesions were present on the larger roots and that root laterals were very scarce, a condition found in our 'root rot' disease in Canada. From general observations, therefore, it appeared as though there was present in England a root rot disease very similar in appearance to that found in Canada and the United States of America.

To ascertain if this was actually the case, isolations were made from lesioned roots and many fungi have been thus obtained. Of these, many were obviously 